\title{
USE AND ABUSE OF TAX REGULATIONS IN STATUTORY CONSTRUCTION
}

\author{
By RANDOLPH E. PAUL $\uparrow$
}

"Castle or no castle, let us row as if it were there." 1

The case of Helvering v. R. J. Reynolds Tobacco Company, ${ }^{2}$ decided by the Supreme Court on January 30,1939, bids fair to become a landmark in tax law; yet the great importance of the case has been widely unrecognized. The Court decided that the Treasury's power to make retroactive amendments changing Treasury regulations or decisions may not be exercised where Congress has by repeated reenactment given its sanction to the existing regulations. Startled persons in the Treasury immediately asked: "Will the Commissioner in the future dare to issue regulations without a fear that his original thoughts on the subject may prove to be a boomerang?" If Congress gave thought to the matter, the natural question would be: "Will we dare in the future to enact a comprehensive revenue act without a complete study of the regulations issued by the Commissioner?" There was some talk of seeking reargument because of the far-reaching echoes of the decision in other fields of law. But reargument is a desperate remedy, and both Government and taxpayers were fortunate in that another case, Hclvcring $v$. Wilshire Oil Company, ${ }^{3}$ furnished the Court with an opportunity to clarify the law on this important subject. Many aspects of problems, both old and new, as to the effect of tax regulations must be re-examined in the light of these significant decisions.

\section{I}

Even with allowances for the complexity of tax law, the bulk of administrative regulations is surprising. Since the advent of the first World War and the attendant increasing intricacy of the statutes, administrative regulations have assumed an ever-increasing importance in tax administration. The current income tax regulations alone run to 358 pages; and the Cumulative Bulletins, containing rulings upon all the outstanding federal taxes, are sufficient to comprise twenty-five sizeable volumes a limitless source of joy for scholars and of confusion for taxpayers.

$\dagger$ Sterling Lecturer on Taxation, Yale Law School; Member of New York, New Jersey and Federal Bars.

Mr. George Allan, of the New York and Illinois Bars, has rendered his usual invaluable assistance in connection with this Article, both by way of indefatigable research and constructive suggestion. Mr. Oscar Sachs of the New York Bar has also made important suggestions.

1. Quoted in Frank, Laiv and the Modern Mind (1930) 320.

2. 306 U. S. 110 (1939), aff'g, 97 F. (2d) 302 (C. C. A. 4th, 1938), which rev'd, 35 B.T.A. 949 (1937).

3. 60 Sup. Ct. 18 (U. S. 1939), rehearing denied, Dec. 11, 1939. 
The conceptualist might argue that these outpourings of regulations should have little, if any, influence upon the courts in exercising their judicial function of interpreting the statute. Especially might this be argued since the Treasury Department has the function of collecting revenue, and it would therefore be expecting too much of human nature that its executive constructions of the statutes should invariably maintain a studious impartiality. ${ }^{4}$ But to accord some weight to executive constructions makes for greater uniformity of interpretation than would result from leaving construction de nov'o to our scattered judicial tribunals. A court cannot reason in a mental vacuum on the meaning of words, and the guidance of "able men, and masters of the subject"s is not lightly to be scouted. Attention is thereby drawn to the practical implications of various possible constructions which might otherwise be overlooked by the judges in their ivory towers. Moreover, if Congress does not interfere with an outstanding administrative construction, it has been argued though with little realism - that even without a reenactment of the statute, Congressional silence impliedly approves the construction. ${ }^{\circ} \mathrm{Also}$, since in many cases members of the administrative branch assist in drafting tax statutes, Congress may well have intended to adopt their viewpoint. $^{7}$ Therefore it is a time-honored doctrine that in construing a statute, "the cotemporaneous construction of those who were called upon to act under the law, and were appointed to carry its provisions into effect, is entitled to very great respect."s

The rule in favor of departmental constructions also assumes that the interpretation is a "fair" and "reasonable" one." The test of fairness or reasonableness naturally defies precise definition. Apparently the courts have meant by this very flexible requirement only that the regulation

4. See the engaging candor in 18 Op. Att'y Gen'l 246 (1SS5); 1 PAUL A:id MFRsTENS, LAW OF FEDERAL INCOAIE TAXITION (1934) \$3.18.

5. United States v. Mloore, 95 U. S. 760, 763 (1S77); of. Williamsport Wire Rope Co. v. United States, 277 U. S. 551 (1928).

6. Hahn v. United States, 107 U. S. 402 (1882).

7. See Comment (1927) 40 Hanv. L. Rev. 469.

8. Edwards' Lessee v. Darby, 12 Wheat. 206,210 (U. S. 1827). This assumes, it is repeatedly said, that the statutory provision in question is onen to ambiguity. Foshland v. Helvering, 298 U. S. 441 (1936). But virtually any statutory phrase whatsoever is open to construction; especially in complex tax statutes it is a chimerical illusion that there ordinarily is a meaning at once apparent to the honest, untutored understanding of the ordinary man. Compare Justice McKenna in Lynch v. Turrish, 247 U. S. 221, 224 (1918). When the courts say that a statutory provision is perfectly plain and unambiguous, they mean in reality that they have already interpreted the statute, and that the statute as so construed needs no further construction. Radin, Stalutory Inferpretotion (1930) 43 HARv. L. REv. 863, 869. In fact, the construction which to one court is so crystal-clear as to render any administrative interpretation superfluous is often the esact opposite of the construction adopted by other tribunals. See Janney v. Comm'r, C. C.A. 3d, Dec. 26, 1939.

9. Sterling Oil \& Gas Co. v. Lucas, 51 F. (2d) 413, 416 (IW. D. Ky. 1931). 
must reasonably conform to the statute which it interprets: would a reasonable man, in the position of the Commissioner, have isstued a similar ruling ? $^{10}$ The regulation does not have to be the best of all possible interpretations in the court's opinion. For example, consider Article 23(o) -1 of Regulations 101, providing that where spouses file a joint return, the percentage limitation regarding deductions for charitable contributions is based upon the separate rather than the aggregate net income; or Article 11 of Regulations 80, providing that where the executor of an estate exercises the option to value an estate as of a year after the decedent's death, the income received by the estate during the year after death should be included in the estate corpus. ${ }^{11}$ Under the language of the statute and all available legislative material, the opposite interpretation would in either case be equally permissible; there is no reason except the interests of the revenue to prefer one solution over the other. The court's conclusion in this situation comes down to the simple question whether the particular court believes that the undoubtedly imperative need for revenue should be followed with Draconian severity as a deliberate judicial policy, or whether the construction most favorable to the taxpayer should be adopted in case of ambiguity. ${ }^{12}$

The construction placed upon a statutory provision by the administrative officials is of course not conclusively binding. ${ }^{13}$ Courts must ulti-

10. Patten, Judicial Review of Treasury Regulations (1926) 4 N.I.T.M. 423. Sec Boske v. Comingore, 177 U. S. 459, 470 (1900): “. . . Those who insist that such a regulation is invalid must make its invalidity so manifest that the court has no choice except to hold that the Secretary has exceeded his authority and employed means that arc not at all appropriate to the end specified in the act of Congress."

11. Upheld in Saks, et al., Ex'rs v. Higgins, 29 F. Supp. 996 (S. D. N. Y. 1939).

12. See De Ganay v. Lederer, 239 Fed. 568, 572 (E. D. Pa. 1917), aff'd, 250 U. S. 376 (1919).

A definite and well-established administrative practice, even though not reflected in the published rulings at all, may be of "persuasive weight" in construing a statute if the practice is not inconsistent with outstanding court decisions. Sec Sanford's Estate v. Comm'r, 60 Sup. Ct. 51, 59 (U. S. 1939), rehearing denied, Dec. 4, 1939; and cf. Union Stock Yard \& Transit Co. of Chicago v. United States, 60 Sup. Ct. 193 (U. S. 1939). The weight given to such a practice cannot be considerable, however, since there is no disclosure of the reasons prompting the practice, as there often is in the case of informal published rulings. Moreover, proving such a uniform Bureau practice is naturally a very difficult if not impossible task, especially when the argument is advanced by the taxpayer, as was true in the Sanford case. And a stipulation as to what the administrative practice was may be excluded from consideration by the court on the ground that it involves a legal, rather than factual, conclusion of the stipulators. See Sanford's Estate v. Comm'r, 60 Sup. Ct. 51 (U. S. 1939). Moreover, the rule as to Congressional validation by rcenactments could hardly add anything to the weight of such a factor, since it would be stretching fiction to the breaking point to attribute to the legislators familiarity with internal Bureau practices.

13. The expressions of the courts in speaking of the deference due to regulations vary all the way from statements that a "regulation rises to no higher dignity than an expression of opinion" [Douglas v. Edwards, 298 Fed. 229, 245 (C. C. A. 2d, 1924), 
mately rely upon their own construction of the statute, not upon the Commissioner's regulations, since it is only by an independent canvassing of the statute's meaning that they can determine whether or not the regulations are reasonably appropriate to the Congressional intent. This is indicated by the fact that a reference to the regulations is usually thrown in toward the end of the opinion, revealing that the court first reached its own conclusion and then examined the regulations to ascertain their reasonableness in the light of that conclusion. Especially is this common in the case of Supreme Court opinions. ${ }^{14}$ More useful than any empty formulae as to the respect due regulations is the teclinique of consulting such practical considerations as the length of time during which the regulation has been outstanding and has therefore presumably been relied upon, ${ }^{15}$ the extent of the discretion with which the Commissioner was clothed by the statute, ${ }^{16}$ and the confusion or inconvenience which would ensue from a reversal of the regulations. ${ }^{17}$

II

Among the innumerable fictions which have formed a part of the science of law, that which holds the record for unrealism is the doctrine that where a statute has been reenacted in the same form after an administrative construction, Congress has silently approved and incorporated the

rev'd ou other grounds, 269 U. S. 204 (1925)] to statements that they are entitled to "great weight" [Spring City Foundry Co. v. Comm'r, 292 C. S. 182, 189 (1934), rchcaring denied, 292 U. S. 613, (1934)] or are not to he overruled "except for weighty reasons" [Fawcus Machine Co. v. United States, 282 L. S. 375, 378 (1931)] or even that they have almost the force and effect of law. (f. Maryland Cas. Co. v. United States, 251 U. S. 342 (1920). But see Koshland v. Helvering, 298 U. S. 441 (1936); Patten, subra note 10. These degrees of verbal rhetoric, however, merely elutter up the interpretative problem, and could be abolished from the judicial lexicon with little loss; it is most unlikely that an actual judgment in many cases would have been different if the court had started out with exactly the opposite formula. [Cole, From Treasury Decision to Ittdicial Decision (1934) 12 Tax MAG. 531 ; Comment (1939) 52 Hanv. L. REv. 1163, 11G4].

14. Sometimes, in fact, a ruling contrary to the Court's conclusion is not even accorded the honor of mention. United States v. Hudson, 299 U. S. 495 (1937). But see United States v. Kirby Lumber Co., 284 U. S. 1, 3 (1931), in which Justice Holmes contented himself with the terse statement that there was no reason why the regulations regarding cancelled bonds "should not be accepted as a correct statement of the law:"

15. But see Dayton Bronze Bearing Co. v. Gilligan, 281 Fed. 709, 714 (C. C. A. 6 th, 1922) (administrative construction given "due consideration" regardless of the length of time it has been enforced by the Department).

16. See New Creek Co. v. Lederer, 295 Fed. 433 (C. C. A. 3d, 1924), ccrl. denicd, 265 U. S. 581 (1924) (arising under the 1916 Act, Section 12 of which allowed, in the case of corporations, a "reasonable" depletion under rules preseribed by the Secretary of the Treasury) ; Murphy Oil Company v. Burnet, 287 U. S. 299 (1932), relicaring dcricd, Jan. 9, 1933. See also the inventory provision $[\$ 22(c)]$, and the provision in Section 45 empowering the Commissioner to reallocate the income of affiliated corporations.

17. United States v. Dickson, 15 Pet. 141 (U. S. 1841). 
existing ruling. ${ }^{18}$ Our tax laws are reenacted so repeatedly that this rule is invoked more often than the general statement as to the validity of regulations standing alone. Unfortunately, the reenactment rule presumes an attention on the part of Congress in connection with tax legislation which is more ideal than real. The thought is that Congress, each time it passes a revenue act, has omniscience as to all outstanding regulations and judicial decisions and that it will be thoroughly diligent to correct by legislation any interpretation with which it disagrees. ${ }^{10}$ There follows the thought that inaction is action in that a failure to legislate implies an agreement with all outstanding regulations, without any apparent distinction as to their interpretative or legislative character. ${ }^{20}$

Anyone cognizant of the processes and exigencies of tax legislation is perfectly familiar with the simple fact that any such presumption is not only artificial, but in large part unfounded. This is particularly true with respect to regulations which are relatively new, and which have been followed by only one or two statutory reenactments. The time lag in tax law ${ }^{21}$ is such that frequently many years elapse before litigation brings a regulation of doubtful validity to the battle line. Of course, the regula-

18. The unreality of the rule is emphasized in cases such as the Rcynolds case, in which the applicable statutory provision was recnacted in identical form both subsequent to the original regulation and again after an amendment to the regulation.

Strictly speaking, the term "reenactment" should possibly include only those blanket passages of an entire act such as occurred in 1932, 1934, 1936, 1938 and in the enactment of the Internal Revenue Code of 1939; of lesser weight in this connection should be piecemeal amendments (such as were enacted in 1935 and 1937) which merely fail to revise the remaining provisions. The passage of the 1939 Code may therefore weaken the doctrine of statutory approval, since thereafter there will generally be only detailed amendments to specific Code sections rather than a general repassage. See Alvord, Treasury Regulations and the Wilshire Oil Case (Privately published manuscript, 1939) 14; but cf. Comm'r v. Haines, 104 F. (2d) 854 (C. C. A. 3d, 1939); Helvering v. Cronin, 106 F. (2d) 907 (C. C. A. 8 th, 1939).

19. See McCaughn v. Hershey Chocolate Co., 283 U. S. 488, 492 (1931), rchcaring denied, Oct. 12, 1931; National Lead Co. v. United States, 252 U. S. 140,147 (1920).

20. Massachusetts Mutual Life Ins. Co. v. United States, 288 U. S. 269, 273 (1933). In Bryant Estate v. Comm'r, and Comm'r v. Hallock, now pending in the United States Supreme Court, the same contention is made by the taxpayers in arguing the implicd adoption by Congress of Helvering v. St. Louis Union Trust Co., 296 U. S. 39 (1935) and the Treasury regulations following that case. In 1937, after the St. Lonis case, Article 17 of Regulations 80 was amended by expressly exempting from estate tax any transfer in which the decedent-transferor reserved a mere possibility of reverter. This amended regulation was outstanding when the 1937 and 1938 Acts were passed and also when Section 302(c) became Section $811(c)$ of the 1939 Internal Revenue Code. See Sanford's Estate v. Comm'r, 60 Sup. Ct. 51 (U. S. 1939), in which the Court states at p. 60 : "A change of practice to conform to judicial decision . . . will be accepted as controlling when consistent with our decisions."

21. See Traynor, Administrative and Judicial Procedure for Federal Income, Estate, and Gift Taxes-A Criticism and a Proposal (1938) 38 CoL. L. REv. 1393. 
tions themselves are a matter of public record."2 But Congress in tax legislation usually hits only the high spots which are forced upon its attention by conspicuous judicial decisions or which are called to its attention by the Treasury and diligent taxpayers. ${ }^{23}$ Even long-outstanding regulations are hardly in fact approved by a legislative reenactment of the statute without change. The very regulations involved in the Reynolds case went through many editions, and there vere years of litigation on the subject before they were changed. ${ }^{24}$ This is true in many cases; it is particularly true of a regulation in favor of the taxpayer. In such cases taxpayers will not object and the Commissioner is in the position of having to attack his own regulations or amend them by Treasury decision. ${ }^{25}$ No person, therefore, could honestly claim that the doctrine of approval by reenactment has any solid factual foundation.

It would now, of course, be a hopelessly late date to deplore this wellsettled rule of construction. On the whole there is no reason to deplore it; though one may denounce the reasoning of the doctrine as a mockery of the facts, one may yet applaud its results. Undoubtedly in most cases it does produce pragmatically desirable results. ${ }^{20}$ True, the partiality, rather than impartiality, of administrative rulings constitutes an objection to the theory of validation even where the regulation has been long outstanding. But despite this fact, the doctrine merits some of the respect which the courts have extended to it. One may speak of a law of inertia in law as well as in physics, ${ }^{2 \pi}$ and upholding the status quo has always been a fundamental policy of the law and may, in fact. have a special

22. See Griswold, Governntent in Ignorance of the Lan-A Plca for Beller Publicetion of Executtive Legislation (1934) is HARv. L. Rev. 198.

23. Where a regulation was actually considered by Congress in connection with a reenactment of the statute, as where there is an unsuccessful attempt to change the linw because of its administrative construction, there is some rational basis for saying that a regulation has become embedded in the statute. Comment (1939) 52 Harv. L Rv. 1163, 1170. See Pfaff v. Bender, 38 F. (2d) 642 (E. D. La. 1929), aff'd, 38 F. (2d) 649 (C. C. A. 5th, 1930), aff'd, 282 U. S. 127 (1930). And see Watts v. Comm'r, 75 F. (2d) 981, 983 (C. C. A. 2d, 1935), aff'd, 296 U. S. 387 (1935), involving a change by Congress of a related part of the statute.

24. See cases cited in Note (1939) 39 CoL. L. Rev. 716, 718, n. 8.

Miatters might be different if revenue acts were few and if reenactment were a mattcr involving meticulous study of every phase of the statute and regulations. But this is not true. We have the disease of almost annual revenue acts; and the revenue acts we do have are laden with detail. There is great fecundity even if the quality of the progeny is debatable. Even the members of the Congressional committees having charge of drafting amendments rarely make any meticulous examination into the endless ramifications of the regulations. Indeed, the very provision in the statute delegating to the Treasury the power to make all necessary regulations shows an intention on the part of Congress to wash its hands of all attention to such technical details.

25. See Sanford's Estate v. Comm'r, 60 Sup. Ct. 51 (U. S. 1939).

26. See Gray, Nature and Sources of Law (1st ed. 1909) \$\$74-\$9.

27. Cole, Fron Treasury Decision to Iudicial Decision (1934) 12 Tax Mrag. 531. 
relevance in tax law. Applied as a persuasive but not a conclusive factor, the principle affords an increased degree of predictability without causing any inordinate hardship to taxpayers. ${ }^{28}$ In other words, the same reluctance properly shown by the courts in declaring an act of Congress not to be within the powers granted by the Constitution is relevant when the issue is the validity of a well-established administrative construction. ${ }^{20}$

The rule as to reenactment, therefore, accomplishes a desirable result in adding stability to regulations upon which taxpayers are forced to rely. In view, however, of the fictional quality of the premise underlying the reenactment rule, there is special need for a scrutiny of the consequences of the rule and the limits of its application. We are deliberately substituting "a fraction of reality for the complete range of causes and effects." ${ }^{30}$ And we need to be careful that the rule does not do more harm than good - that a fiction intended for the sake of justice should not work "contrary to real truth or substance of the theory." 31 The net result of the rule should be analyzed. ${ }^{32}$

As with respect to regulations standing alone, analysis may first be made from the approach of the weight actually attributed by the courts to the reenactment doctrine in arriving at a construction. Is the court putting dress clothes upon the expression of its own opinion, or is it refraining from an opinion because it feels itself bound, or is it bowing to administrative pressure though it disagrees?33 The reenactment rule

28. Ibid.

29. Boske v. Comingore, 177 U. S. 459 (1900).

30. Vaininger, The Philosophy of As If, quoted in Frank, LAw and the Modern MrND (1930) 327.

31. Quoted by FRANK, op. cit. supra note 30, at 167 .

32. The doctrine does not apply to informal rulings which do not rise to the dignity of regulations. See Helvering v. New York Trust Co., 292 U. S. 455 (1934). A merely nominal effect is given by most decisions to such informal rulings. But note the reliance placed on a Gen'l Counsel Memo. in Helvering v. Wilshire Oil Co., 60 Sup. Ct. 18, 23 (U. S. 1939), rehearing denied, Dec. 11, 1939.

Nor will the rule be applicable where the Treasury practice has not been consistent [Central Real Estate Co., 17 B.T.A. 776 (1929), petition for review dismissed, 47 F. (2d) 1036 (C. C. A. 5th, 1931)], or where the regulation is itself ambiguous. See Burnet v. Chicago Portrait Co., 285 U. S. 1, 16 (1932) (". . . . ambiguous regulations are of little value in resolving statutory ambiguities."). The fact that the administrative interpretation had only a brief career before the reenactment may also preclude any argument of legislative approval. Iselin v. United States, 270 U. S. 245 (1926).

The legislative materials on a given section might-in fact usually would-show a complete lack of any reference to departmental rulings, and it might be argued that such a circumstance would disprove the supposed intent to effect an implied incorporation of the regulation. But such negative evidence would undoubtedly not avail to defeat the reenactment rule, which is based not so much upon active acquiescence as upon the assumption that the ruling would have come to the affirmative attention of Congress if it had involved any violent departure from the spirit of the act.

33. See Securities Allied Corp. v. Comm'r, 95 F. (2d) 384 (C. C. A. 2d, 1938), ccrt. denied, 305 U. S. 617 (1938); Comment (1939) 52 HARv. L. REv. 1163, 1167. 
has suffered the fate of many convenient rules of statutory construction and has been stated so frequently that various statements of it differ materially. ${ }^{34}$

Consequently the degree of compulsion in the reenactment rule is a matter of doubt. It is infrequent that the courts are willing to rest their conclusion wholly upon the regulations even when they are buttressed with the implied sanction of reenactment. ${ }^{35}$ Even with legislative reenactment, the regulation in order to be applied must be reasonable and is usually referred to only as strong evidence, rather than the sole support of the construction laid down by the courts. The opinion in the recent Wilshire case makes it clear that the reenactment doctrine is not an absolute, ironclad rule, and if anything might be suggested as a measure of the degree of compulsion in the rule, the length of the period during which a regulation has been outstanding is a sensible test. Where a regulation has been outstanding for a long time, as was the regulation involved in the Reynolds case, and where it has been followed by several reenactments of the statute, its past may become practically impregnable. ${ }^{3 B}$ But where a regulation has been in effect but a short time and has been ratified by only one statutory reenactment, little weight need be given to the negative sanction involved in the reenactment. Any other rule would fly in the face of the realities of the legislative process, since it takes time to develop the implications of any regulation on a controversial subject. There must be a conflict of ideas, and cases must be brought to the courts before it can reasonably be assumed that the subject of the regulation

34. Iudge Stone pointed out in Walker v. United States, 83 F. (2d) 103, 105-7 (C. C. A. Sth, 1936) a number of variations in the statement of the rule-such as that the executive construction after repeated reenactment has the "force of law" "; that it "'must be accepted" ; that it "'will not be overturned except for very cogent reasons" "; that it should be given " "great weight, even if we doubted the correctness of the ruling" ; that it will not be "'disturbed except for reasons of weight" ; that "were the matter less clear" the court " should be constrained' to follow it"; and that it should be followed "'when not plainly erroneous". Iudge Stone concludes that a "safe statement" of the rule is that "where a statutory provision is ambiguous, and the exceutive department which must apply and enforce it declares a construction (not in itself ambiguous . ...) for administrative purposes, and thereafter Congress re-enacts the provision without substantial change, the courts will accept that construction unless it be 'plainly erroneous.' "

35. See Taft v. Comm'r, 304 U. S. 351 (1938). It is true that in Helvering v. Winmill, 305 U. S. 79 (1938), upholding a regulation that brolers' commissions on the purchase of stock should be added to the stock's cost basis rather than deducted as an expense, Justice Black confined his discussion almost completely to the Treasury regulations. See Note (1938) 33 IrL. L. Rev. 468. But even here the Court unquestionably assumed the independent reasonableness of the construction set forth in the regulations, which were plainly an admissible interpretation of the statute and which neither the Treasury nor Congress had evinced any desire to alter. Compare the Reynolds case, p. 670 et seq. infra.

36. See Oil Shares, Inc., 29 B.T.A. 664, 669 (1934). 
has come to the attention of Congress. Moreover, any other rule would be a perilous one. It would have the twin effects of compelling timidity in a rule-making Commissioner and requiring Congress to examine into every phase of the revenue regulations before it dared pass a comprehensive revenue act.

And the weight to be given to the rule under discussion should also depend upon whether there are outstanding Board and court decisions in conflict with the rule stated in the regulations. Here we have a conflict of statutory rules of construction, for a judicial, as well as an administrative, construction of a prior act may be sanctioned by Congressional reenactment. In other words, where Congress uses language which has been construed by the courts it must be assumed to have employed that language in the sense in which the courts had previously construed it. ${ }^{37}$ This presumption, in fact, is more defensible than the related presumption as to administrative constructions, since Congressional familiarity with a judicial construction is equally possible and since a judicial holding is a more impartial ruling, rendered in a litigated proceeding rather than in an ex parte regulation. ${ }^{38}$

The most familiar limitation upon the doctrine as to reenactment is the qualification that if the regulation definitely goes beyond the limits of the statute, no amount of legislative reenactment will validate the ruling. ${ }^{39}$ To hold otherwise would mean that taxpayers could never rely even upon the clearest terminology of the statute. A regulation which does not carry into effect the will of Congress as expressed in the statute. and which operates to create a rule out of harmony with the statute, is "a mere nullity." 40 Thus in Blatt Company $v$. United States," the con-

37. Burnet v. Thompson Oil \& Gas Co., 283 U. S. 301 (1931) ; McCaughn v. Hershey Chocolate Co., 283 U. S. 488 (1931), rehearing donied, Oct. 12, 1931; Hecht v. Malley, 265 U. S. 144 (1924); Latimer v. United States, 223 U. S. 501 (1912).

38. The Government itself may in particular litigated cases be taking a position inconsistent with that announced in the outstanding regulations. Cf. Hadley Falls Trust Co. v. United States, 22 F. Supp. 346 (D. Mass. 1938). This fact could hardly of itsclf preclude the doctrine of legislative adoption from applying, since the fact that formal regulations are still outstanding and unamended is more significant than the fact that in an isolated case the government may be attacking the same regulations. Nevertheless. the fact that the Government itself does not regard the administrative interpretation as universally controlling does reveal that administrative needs and interests are not always best served by the rule announced in the regulations, which somewhat weakens the premise for implied legislative acceptance. Cf. Sanford's Estate v. Comm'r, 60 Sup. Ct. 51 (U. S. 1939).

39. United States v. Maryland Casualty Co., 49 F. (2d) 556 (C. C. A. 7th, 1931), cert. denied, 284 U. S. 645 (1931) ; Titsworth v. Comm'r, 73 F. (2d) 385 (C. C. A. 3d, 1934). See also First Nat. Bank of Greeley v. United States, 86 F. (2d) 938, 939 (C. C. A. 10th, 1936), qualifying the rule as to legislative adoption of an executive construction by the phrase "unless it is clearly inconsistent with a statute." See Note (1939) 39 CoL. L. REv. 716, 720.

40. Manhattan Gen'l Equipment Co. v. Comm'r, 297 U. S. 129, 134 (1936), rehcaring denied, 297 U. S. 728 (1936). 
troversy centered about the now twenty-year-old counterpart of Article 48 of Regulations 45, promulgated in 1920 and providing that a lessor might be taxed annually for a proportionate share of the value of lessee's improvements. The lower court in ruling against the taxpayer expressed the view that Congress had, by reenactments over a period of many years, put its seal of approval upon the administrative interpretation. This theory, however, was rejected by the Supreme Court without the dignity of any answer beyond the brief statement that "Treasury Regulations can add nothing to income as defined by Congress." The regulation was therefore rejected as invalid despite its numerous repetitions.

Similarly, the Eighth Circuit Court of Appeals recently had occasion to point out that "A plainly erroneous departmental construction does not become correct by any subsequent reenactment of the provision of the statute to which it pertains." ${ }^{22}$ In this case the taxpayer had established a term trust, administered by himself as trustee, and the Government was attempting to tax the income to him under Article 166-1 of the income tax regulations. Even though this article had appeared in successive regulations, the court held the interpretation roid as being "in direct conflict with the plain language and the meaning of the statute." The court's position was bolstered by the fact that a year before the regulations in question had been promulgated, the Commissioner had failed in an attempt to have the statute itself amended to conform with his views. In the eyes of the court, this fact clearly demonstrated the Commissioner's lack of faith in his own contention under the existing phraseology of the statute.

Also, where the law is so plain as to render the particular regulation superfluous, the subsequent reenactment of the statute does not constitute an adoption of the administrative construction. ${ }^{43}$ In other words, even if the regulation is not palpably erroneous, legislative reenactment may not operate to make it part of the law if the statute itself is sufficiently clear even without the aid of any regulation. If there was no need for the regulation originally, the reenactment of the statute will not supply that need.

41. 305 U. S. 267 (1938). See also United States v. Mrissouri Pacific R. R., 278 U. S. 269 (1929) ; Boca Ratone Co. v. Comm'r, 86 F. (2d) 9 (C. C. A. 3d, 1936).

42. Clifford, Jr. v. United States, 105 F. (2d) 585 (C. C. A. Sth, 1939). See also F. W. Woolworth Co. v. United States, 91 F. (2d) 973 (C. C. A. 2d, 1937), cert deried, 302 U. S. 768 (1938), overturning the method for computing the foreign income tax provided in Article 131-8 of the regulations; Comm'r v. Shattuck, 97 F. (2d) 790 (C. C. A. 7th, 1938), permitting the use of "blockage" in valuing stock, despite continted regulations to the contrary; Herman A. Holsten, Ex'r, 35 B.T.A. 568 (1937), aff'd for curiam, 93 F. (2d) 1002 (C. C. A. 2d, 1937) (voiding a portion of Art. 50, Reg. 80); Hughes Tool Co., 40 B.T.A. No. 147 (1939) (regarding the provisions of Reg. 75, Art. 41 (d) as to consolidated returns).

43. Biddle v. Comm'r, 302 U. S. 573, 582 (1938); Koshland v. Helvering, 298 U. S. 441 (1936) ; Louisville \& Nashville R. R. v. United States, 282 U. S. 740 (1931). 
The reenactment rule must of course also be qualified by the thought that the Commissioner cannot, even by a regulation which conforms to the statute, undertake to subject to tax what is not income. Thus in two recent cases ${ }^{44}$ an administrative interpretation which had survived the passage of four revenue acts was declared invalid despite this history of apparent Congressional approval. By Article 58 of income tax Regulations 74 , the taxpayer had been given the option of reporting the entire proceeds from a sale of stock rights in gross income or apportioning part of the cost of the original stock to the rights. The first alternative, however, had already been declared unconstitutional by the Supreme Court. ${ }^{45}$ Even though the regulations offered a second, and constitutional, method of reporting the gain upon a sale of rights, it was held that no amount of legislative reenactment could give validity to regulations which were beyond the legislative power of Congress itself. ${ }^{40}$

\section{III}

The Reynolds case involved the question of gain to a corporation on the resale of treasury stock. The Reynolds Company on various occasions between 1921 and 1929 purchased its own Class B common stock. The stock so purchased was treated as treasury stock; its cost was entered in the company's accounts as "Investments in Non-competitive Companies." No increase or reduction of capital stock was made on account of the stock so purchased and its resale from time to time. In 1929 the company sold some shares at a profit over cost of approximately $\$ 285,000$. This profit went through the company's books as cash and was added to its surplus. In the company's return it was treated as non-taxable income. In 1936 the Commissioner asserted a deficiency for 1929 on the basis of this profit, basing his claim upon Regulations 74, Article 66, as amended by T. D. $4430,{ }^{47}$ promulgated May 2, $1934 .{ }^{48}$ The Board sustained the

44. Continental Bank \& Trust Co. v. United States, 19 F. Supp. 15 (1937); Walter E. Buck, 40 B.T.A. 536 (1939). Cf. Hewitt Realty Co. v. Comm'r, 76 F. (2d) 880 (C. C. A. 2d, 1935).

45. Miles v. Safe Deposit \& Trust Co., 259 U. S. 247 (1922), applying the theory of Eisner v. Macomber, 252 U. S. 189 (1920).

46. Where the administrative interpretation raises issues of constitutional power, the doctrine of approval by reenactment would involve the unwarranted assumption that Congress intended to exceed its legislative powers; therefore, in such a case the reenactment doctrine must yield to the even stronger constructional canon that Congress intended a meaning which would clearly preserve the constitutionality of the statute.

47. XIII-1 CuMr. Buxt. 36 (1934).

48. This new Treasury decision was largely prompted by the decision of the First Circuit Court of Appeals in Comm'r v. S. A. Woods Machine Co., 57 F. (2d) 635 (C. C. A. 1st, 1932), cert. denied, 287 U. S. 613 (1932), although another inducement lending to the promulgation of the ruling may have been the possibility under the 1934 Act of taxing corporations upon gains from such transactions without a full deduction for losses on similar sales. See Reply Brief for Petitioner, p. 19, E. R. Squibb \& Sons v. Comm'r, 98 F. (2d) 69 (C. C. A. 2d, 1938), nodified, 102 F. (2d) 681 (C. C. A. 2d, 1939). 
Commissioner. The circuit court of appeals reversed the Board and held with the taxpayer.

The rule of the regulations before amendment was that if a corporation purchased any of its stock, and held it as treasury stock, the sale thereof constituted a capital transaction so that the proceeds should be treated as capital and not as income. The supplanted regulations contained the following categorical general statement: "A corporation realizes no gain or loss from the purchase or sale of its own stock." T. D. 4430, on the other hand, qualified this broad rule by a statement that where a corporation dealt in its own shares "as it might in the shares of another corporation, the resulting gain or loss is to be computed in the same manner as though the corporation were dealing in the shares of another." This provision of the regulations was meant to change the rule in effect under Regulations 74 before amendment by T. D. 4430 and also the rule of previous regulations. The unqualified administrative construction in previous regulations had been uniform with respect to each of the revenue acts beginning with the 1913 Act and extending to the 1932 Act, ${ }^{50}$ and this uniform construction had been approved by the enactment of a number of successive revenue acts. Of course, a number of revenue acts were also adopted after May 2, 1934, when T. D. 4430 was promulgated. ${ }^{51}$

49. The new Treasury decision added the language: ". . . . So also if the corporation receives its own stock as consideration upon the sale of property by it, or in satisfaction of indebtedness to it, the gain or loss resulting is to be computed in the same manner as though the payment had been made in any other property. Any gain derived from such transactions is subject to tax, and any loss sustained is allowable as a deduction where permitted by the provisions of applicable statutes."

50. For authorities sustaining this statement, see fHelvering v. R. J. Reynolds To- bacco Co., 306 U. S. 110, 114, n. 9 (1939). It is noteworthy, however, that a number of decisions prior to the Reynolds case had refused to follow the original regulations where a company actually had dealt in its own stock as it might in the stock of a separate corporation. Note (1939) 39 CoL. L. REv. 716, 718.

51. Thus raising a conflict between presumptions. Note (1939) 39 COL L. REv. 716, 718; Comment (1939) 52 Harv. L. Rev. 1163, 1169. Commenting on this aspect of the decision in the Reynolds case, Professor Traynor has said: "It is a paradoxical situation that the later interpretation should yield to the earlier one when Congress by continuing to reenact the statutory provisions impliedly gives its blessing to both of the Treasury's conflicting regulations." Traynor, Tax Decisions of the Supreme Court of the United States, 1938 Tern (Paper read at Nat. Tax Conference, 1939) 73. However, Congress by its repeated reenactments of the statute had already declared that for the year 1929 the sale of treasury stock by a corporation should not give rise to tasable income. Under such circumstances it is likely that Congress itself could not in 1934 have validly amended Section 22(a) with respect to such transactions consummated in 1929. Cf. People ex rel. Beck v. Graves, 9 N. Y. Supp. (2d) 217 (1939); therefore it was even more clear that the same result could not be reached by the Commissioner's regulations or by any implied Congressional adoption through reenactment of the statute after the change in the regulations. 
These facts raised the question whether the amendment effected by T. D. 4430 , and impliedly sanctioned at least as to the future by subsequent reenactments of the statute, could be applied retroactively in the face of an administrative construction to the contrary which had also been sanctioned by subsequent reenactments of the statute. In its brief in the Reynolds case, the Government cited what it called an "impressive" number of cases supporting the reenactment rule. ${ }^{52}$ The Government also pointed to two cases in which the Supreme Court in fact gave effect to amended regulations despite reenactment of the statutory provisions while former regulations were in force. In one of these cases, Murphy Oil Company $v$. Burnet, ${ }^{53}$ the regulations, as amended in 1926, were held to govern the allowance for depletion in respect of royalties received in 1919 and 1920, when the 1918 Act was in force. The other of the two cases, Morrissey v. Commissioner, ${ }^{54}$ involved the meaning of the term "association." In determining that meaning for purposes of the 1918 and 1921 Acts, the Commissioner promulgated a regulation to the effect that if the beneficiaries of a business trust had a voice in the business, the trust was an association. ${ }^{55}$ Then the Supreme Court decided Hecht $v$. Malley, ${ }^{56}$ and the Treasury issued new regulations to the effect that even in the absence of control by the beneficiaries a trust constituted an association if the trustees of an operating trust were associated like corporate directors for the purpose of a business enterprise. ${ }^{.7}$ The Court held that the subsequent regulations should be applied despite legislative reenactment while the earlier regulations were in force, and stressed the range of administrative power to re-examine and reformulate its construction of the statute in the following language:

52. Brewster v. Gage, 280 U. S. 327, 337 (1930); Poe v. Seaborn, 282 U. S. 101, 118 (1930) ; Burnet v. Thompson Oil \& Gas Co., 283 U. S. 301, 307 (1931); McCaughn v. Hershey Chocolate Co., 283 U. S. 488, 492 (1931); United States v. Kirby L. Co., 284 U. S. 1,3 (1931); Old C. R. R. v. Comm'r, 284 U. S. 552, 557 (1932); Murphy Oil Co. v. Burnet, 287 U. S. 299, 302, 307 (1932), rehearing denied, Jan. 9, 1933; Mass. Mut. L. Ins. Co. v. United States, 288 U. S. 269, 273 (1933); United States v. Dakota-Montana Oil Co., 288 U. S. 459, 466 (1933) ; Reinecke v. Smith, 289 U. S. 172, 175 (1933) ; Helvering v. Bliss, 293 U. S. 144, 151 (1934) ; Zellerbach Paper Co. v. Helvering, 293 U. S. 172, 178, 180 (1934); Old Mission Portland Cement Co. v. Helvering, 293 U. S. 289, 293 (1934) ; Hartley v. Comm'r, 295 U. S. 216, 220 (1935) ; McFeely v. Comm'r, 296 U. S. 102, 108 (1935) ; Morrissey v. Comm'r, 296 U. S. 344, 355 (1935); United States v. Safety Car Heating \& Lighting Co., 297 U. S. 88, 95 (1936) ; Lang v. Comm'r, 304 U. S. 264, 270 (1938) ; Helvering v. Winmill, 305 U. S. 79, 83 (1938). See also, Heiner v. Colonial Trust Co., 275 U. S. 232 (1927); Burnet v. Brooks, 288 U. S. 378, 393 (1933).

53. 287 U. S. 299 (1932), rehearing denied, Jan. 9, 1933.

54. 296 U. S. 344 (1935).

55. U. S. Treas. Reg. 45, Art. 1504; U. S. Treas. Reg. 62 , Art. 1504, following the Supreme Court decision in Crocker v. Malley, 249 U. S. 223 (1919).

56. 265 U. S. 144 (1924).

57. T. D. 3748, IV-2 Cusr. Bulc. 7 (1925), amending U. S. Treas. Reg. 65, Art. 1504. 
"As the statute merely provided that the term 'corporation" should include 'associations,' without further definition, the Treasury Department was authorized to supply rules for the enforcement of the Act within the permissible bounds of administrative construction. Nor can this authority be deemed to be so restricted that the regulations, once issued, could mot later be clarified or enlarged so as to meet administrative exigencics or conform to judicial decision. ... We find no ground for the contention that by the enactment of the Revenue Act of 1924 the Department was limited to its previous regulations as to associations. ..."

These two cases did not dissuade the Supreme Court from the view that the Commissioner had no power retroactiz'dy to change the earlier regulations. The Supreme Court, affirming the court below. decided that no retroactive effect was permissible. ${ }^{69}$ Section 605 of the 1928 Act gave the Treasury power to correct misinterpretations, inaccuracies, or omissions under regulations, and thereby to affect cases in which taxpayers' liability had not been finally determined, unless in the judgment of the Treasury some good reason required that such alterations operate only prospectively. ${ }^{60}$ The clear implication of this provision is that an amended regulation is ordinarily applied aith retroactive effect. ${ }^{\text {or }}$ But

58. Morrissey v. Comm'r, 296 U. S. 344, 354 (1935). (Italics supplied).

59. Cf. Mirphy Oil Co. v. Burnet, 287 U. S. 299 (1932), relicaring desicd, Jan. 9, 1933, in which an original construction was cast aside in favor of a new retresetive version promulgated five years later. Both the first and second rulings had survived two reenactments of the statute. The Supreme Court mentioned the factor of reenactment as sustaining the second regulation, but ignored the same factor in connection with the first ruling, apparently on the ground that the earlier ruling went beyond the pale of the statute. In Aluminum Co. of America v. United States, 24 F. Supp. 811 (W. D. Pa. 1938), the court held that the regulations as to inventories promulgated under the 1932 Act, even if prospectively valid, could not be applied to tax liability for the year 1920 .

60. For a detailed consideration of Section 605, see Paur, Selected Strdies 1:: Federal Taxation (Second Series 1938) 79.

61. The mere use of the word "retroactive" is frequently sufficient to malse even the hardiest of taxpayers turn pale. Nevertheless, the retroactivity of interpretative regulations is not per se any basis for objection, even though the regulations are made retroactive for a greater period than the permissible period of retresctivity for new statutory amendments. See Welch v. Henry, 305 U. S. 134 (1938), relicaring desied, 305 U. S. 675 (1938). A practical differentiation must, of course, be drawn between regulations supplanting or amending prior interpretations and those which represent the Commissioner's first construction of the statute. In the first situation, taxpayers will have relied upon the first construction, and there is an obvious inequity in a retrospective application of amendments changing that construction. Even the current possibility of closing agreements for future as well as completed transactions is too narrow a device to afford adequate protection against such inequities.

Nevertheless, in view of the fact that regulations are generally inferprelatize, rather than legislative, they must ordinarily be granted retrospective application. Their operation in this respect has been compared to that of a judicial construction: buth types of rulings theoretically construe the law as it existed continuously since the date of its 
this statutory authority, the Court held, did not extend to the length of authorizing the Treasury to repeal a rule of law established by its own administrative construction reinforced by a number of statutory reenactments.

It does not require a vivid imagination to visualize the sweeping implications of this decision. Though the Reynolds opinion was carefully limited to an executive interpretation of a "general" provision stch as Section 22(a) which had been "uniform" for many years, vague implications of the opinion promised trouble for both taxpayers and Government. $^{2}$ Although the result was a victory for the taxpayer upon its particular facts, it is frequently true in tax law as well as elsewhere that "Nothing except a battle lost can be half so melancholy as a battle won." "y The grim fact is that the application of the reenactment rule can more often be urged with profit by the Government than by taxpayers. Furthermore, if there is a danger that every executive construction may become unalterably frozen into the statute by reenactment, the inevitable tendency will be for the Treasury to rule every doubtful issue increasingly in its own favor and force taxpayers into increased litigation.

Also, the Reynolds case could hardly have meant to establish a rule that a plainly erroneous regulation may be validated by subsequent stattrtory reenactment; the Supreme Court must have meant to limit the effect of the decision to regulations interpreting broad provisions of the statute in respect to debatable questions. The opinion of the Supreme Court refers to the opinion of the court below, which was affirmed, as having found it unnecessary to decide the question whether a gain on the sale of treasury stock is capital gain and not income," because this was "at least a debatable question and the regulation was, therefore, proper as an interpretation of the meaning of the section." ${ }^{05}$ Mr. Justice Roberts

enactment. See the last sentence of Justice Sutherland's opinion in the Manhattan General Equipment Co. case, 297 U. S. 129 (1936), rehearing denied, 297 U. S. 728 (1936), in which this similarity was noted. Taxpayers have been notably unsuccessful in resisting retroactive treatment on the ground of equitable estoppel, either as to reliance upon general regulations or specific agreements with the Government. 5 PAUL AND MERTENS, LAW of Federal Income Taxation (Supp. 1938) \$53.07. Any serious inequity from retroactive application may, of course, be corrected by the legislature, as the inequity of the judicial interpretation in Hendler v. United States, 303 U. S. 564 (1938), rehearing denicd, 304 U.S. 588 (1938) was removed by Section 213 of the 1939 Act. Cf. Field, Thic Ligal Force and Effect of Treasury Interpretation in THE Federal Incone Tax (1921) 90, $109-111$.

62. With respect to the Government, this was particularly true as to the virtual emasculation of Section 605.

63. Arthur Wellesley, Duke of Wellington, in a despatch of 1815.

64. This is a curious way in which to state this issue since capital gains arc, of course, taxable income. Mr. Justice Roberts undoubtedly meant to contrast income transactions and capital increment.

65. Helvering v. Reynolds Tobacco Co., 306 U. S. 110, 114 (1939). 
then went on to add: "We agree that $\S 22(a)$ is so general in its terms as to render an interpretative regulation appropriate." cs This language must be regarded as a premise of the Reynolds case, and as an indication that the Supreme Court did not regard the original ruling as palpably erroneous. As has been pointed out, ${ }^{67}$ where the law is plain, the subsequent reenactment of the statute does not constitute the adoption of an administrative construction which is in plain contravention of the statute. ${ }^{68}$ Thus in the Manhattan General Equipment case, ${ }^{63}$ it was stated that, to be valid, a regulation must be consistent with the statute and must be reasonable. The original rule, to be validated by reenactment, must be correct, or if it does not reflect the only correct rule, it must reflect a rule that is not plainly erroneous. If these conditions are not fulfilled, the regulation never acquires any original life, and an amended regulation becomes the primary and controlling rule in respect to the situation presented because it first points the way for correctly applying the antecedent statute. Thus, amended regulations have often been applied to transactions wholly completed before the change, where the old regulation was in conflict with the statute but the new regulation was in harmony with it. ${ }^{\mathrm{T}}{ }$ Those who depend blindly upon the reenactment rule without examination into the character and reasonableness of an original regulation which has been followed by statutory reenactment may be rudely awakened when the court's attention is called in their cases to this necessary qualification of the Reynolds doctrine.

Other questions rushed to the foreground as a result of the Reynolds case. To what extent was the rule there established founded upon the specific facts of that case, particularly the fact that the regulation there attempted to be changed had been in effect and relied upon for so many

66. Compare the language of the same Justice in Koshland v. Helvering. 293 U. S. 441,446 (1936).

67. See p. 668 supra.

68. Where the line should be drawn between this situation and the Reyrolds case is a question of degree which will give trouble until "a mathematical line is arrived at by the contact of contrary decisions" in relation to each particular tax problem; even then the line will be arbitrary in the sense that "it might equally well have been drawn a little farther to the one side or to the other . . . " Holares, Tur Cosnos Law (1831) 127; cf. Cardozo, The Nature of the Junictal Process (1921) 46.

69. Manhattan General Equipment Co. v. Comm'r, 297 U. S. 139, 134 (1936), rchearing denied. 297 U. S. 723 (1936).

70. Manhattan General Equipment Co. v. Comm'r, 297 U. S. 129 (1936), reiscuring denied, 297 U. S. 728 (1936) ; Murphy Oil Co. v. Burnet, 287 U. S. 299 (1932), rehcaring denied, Jan. 9, 1933; cf. Burnet v. S. \& L. Building Corp., 2sS U. S. 406 (1933).

Even where the original regulation was a permissible construction under the letter of the statute, it is possible that an amended regulation might lie allowed to operate retrospectively despite the Reynolds case if the earlier regulation had not received the added weight of Congressional approval through reenactment. 
years and had been fortified by so many reenactments? ${ }^{71}$ Would the same decision have been made with respect to a regulation which had been followed by a single legislative reenactment; or must there be more than one reenactment, and if so, how many ? ${ }^{72}$ To what extent was the decision in the Reynolds case dictated by the consideration that the regulation in question dealt with an ambiguous statutory provision of doubtful meaning ? $^{73}$ Would the same rule be applied where the statute merely expressed a general rule investing the Treasury with authority to promulgate regt1lations appropriate to its enforcement, ${ }^{74}$ showing clearly that Congress intended to rely upon the practical experience of the Treasury for its administration?

The most pressing question was explicitly reserved ${ }^{75}$ in the Reynolds opinion: does the rule established by a long-outstanding regulation sanctioned by reenactment become imbedded in the statute ${ }^{76}$ to such an extent that even its prospective alteration requires a legislative declaration, or may the Commissioner amend regulations for the future even though the original ruling has received legislative approval by reenactment? If he may not do so, then the added stability produced by the reenactment doctrine may be accomplished at too great a cost - in terms of a shackled Commissioner, who may not change regulations when the development of a law has shown him the way, and also in terms of a requirement upon Congress that it particularly correct each mistaken executive construction under penalty of incorporating it into the fabric of the statute. ${ }^{77}$ Can this delicate balance between stability and flexibility be achieved by the adoption of a rule that is not too inexorable? These questions are as important as any in the tax field today.

IV

It was not long before the question was raised of the power of the Commissioner, in the face of a previous regulation fortified by statutory reenactments, to amend for the future by means of a new regulation contradicting the previous rule. In the famous Ambassador Petroleum

71. In Securities Allied Corp. v. Comm'r, 95 F. (2d) 384, 385 (C. C. A. 2d, 1938), cert. denied, 305 U. S. 617 (1938), Judge Swan refers to "four subsequent re-enactments." See also National Lead Co. v. United States, 252 U. S. 140, 146 (1920).

72. A refinement of this question arises as to whether, in seeking an implied Congressional adoption, the courts may consider the number of reenactments up to the date of litigation or (as would appear more proper) only those which antedated the taxable transaction in question.

73. Koshland v. Helvering, 298 U. S. 441, 446 (1936).

74. Id. at 447 .

75. Helvering v. Reynolds Tobacco Co., 306 U. S. 110, 116 (1939).

76. See E. R. Squibb \& Sons v. Helvering, 98 F. (2d) 69 (C. C. A. 2d, 1938), madified, 102 F. (2d) 681 (C. C. A. 2d, 1939).

77. F. W. Woolworth Co. v. United States, 91 F. (2d) 973 (C. C. A. 2d, 1937), cert. denied, 302 U. S. 768 (1938); Note (1939) 39 CoL. L. REv. 716, 723. 
case, ${ }^{78}$ the question involved was whether development expenses which the taxpayer had elected to deduct for computing taxable net income in the case of oil wells should also be deducted in computing the net income from the property for purposes of Section 204(c) (2) of the 1926 Act; $50 \%$ of this net income was a limitation upon percentage depletion. The Ninth Circuit Court of Appeals held that such expenses should not be deducted, and supported its conclusion by referring to the reenactment of the statute without change after an administrative construction supposedly to the effect that "development" expenses should not be deducted. This case did not go to the Supreme Court, ${ }^{79}$ but the question involved ultimately had to be authoritatively answered and finally came before that Court in the Wilshire case. ${ }^{80}$ In this case the same circuit court of appeals, affirming the Board, ${ }^{\text {s1 }}$ held that in determining the net income of the taxpayer from the property under Section 114(b) (3) of the 1928 Act, there should not be deducted development expenses which the taxpayer, in accordance with an election given him by the regulations, ${ }^{62}$ had deducted for purposes of computing net income upon which the tax was laid. ${ }^{83}$

In concluding that the phrase "net incone . . . from the property" referred to operating profit, the court relied almost entirely upon the reasoning that the Treasury had so construed previous statutes, and that this construction had been ratified by subsequent reenactment of the statute. Certainly the Treasury had so construed and applied the 1921 and 1924 Acts. ${ }^{84}$ When the 1928 Act was passed, the same construction was outstanding as to discoz'ery depletion in the case of mines, but not as to percentage depletion in the case of oil and gas wells. ${ }^{85}$ By regula-

78. Ambassador Petroleum Co. v. Comm'r, S1 F. (2d) 474 (C. C. A. 9th, 1936).

79. The Government did not ask for further review of the Ambassador case but "rather waited for" the IVilshirc case "where the question of the validity of the new regulations could squarely be presented to this Court." Government Brief, p. 23, n. 10, in Helvering v. Wilshire Oil Co., 60 Sup. $C_{t}$. 18 (U. S. 1939), reliearing devied, Dec. 11, 1939.

So. Helvering v. Wilshire Oil Co., 60 Sup. Ct. IS (U.S. 1939), rchearis:g dericd, Dec. 11, 1939, rev'g, 95 F. (2d) 971 (C. C. A. 9th, 1938).

81. Wilshire Oil Co. v. Comm'r, 35 B.T. A. 450 (1937).

82. See U. S. Treas. Reg. 45, Art. 223; Reg. 62, Art. 223; Reg. 65, Art. 225; Reg. 69, Art. 223; Reg. 74, Art. 243; Reg. 77, Art. 236; Reg. 86, Art. 23(m)-16; Reg. 94, Art. 23 (m)-16; Reg. 101, Art. 23 (m)-16.

These regulations have been held valid. Ramsey v. Comm'r, 66 F. (2d) 316 (C. C. A. 10th, 1933), cert. denied. 290 U. S. 673 (1933); Grison Oil Corp. v. Comm'r, 96 F. (2d) 125 (C. C. A. 10th, 1938), cert. desied, 305 U. S. 613 (1938); cf. United States v. Dakota-Montana Oil Co., $28 s$ U. S. 459 (1933).

83. In its brief in the Wilshire case, p. 9, the Government admitted that intangible drilling or development expenses were "on the borderline between deductible business expenses and nondeductible capital outlays."

84. U. S. Treas. Reg. 62, 65, Art. 201 (h).

85. The 1926 Act eliminated discovery depletion (as of 1925) for oil and gas wells and substituted percentage depletion; U. S. Treas. Reg. 69, Art. 201 (h). ". . . it is 
tions issued under the $1928 \mathrm{Act}^{86}$ on February 15, 1929, and foreshadowed in a General Counsel's Memorandum, ${ }^{87}$ issued in September, 1927, the Treasury undertook to follow the practice, disapproved of in the Ambassador case, of compelling the deduction for purposes of the net income limitation upon percentage depletion of development expense which the taxpayer elected to deduct for purposes of computing the net income upon which he was taxed..$^{88}$

It was argued in the Ambassador case, and again in the Wilshire case, that the failure to deduct development expense in computing net income from the property for depletion purposes, when the same expense had been deducted in computing the taxable net income, amounted to a double deduction $^{89}$ and there were many who felt that this argument had considerable force. Judge Garrecht in the Ambassador case replied to this argument by stating that it did not sufficiently consider the administrative and legislative history, and Judge Denman in the Wilshire case replied by saying that the argument had weight only when excluding those "future effects of the regulation on which it is based."

This and further ${ }^{00}$ reasoning did not satisfy a persistent Treasury, which finally contrived to secure a conflicting decision in the $F, H$. E. Oil Company case. $^{01}$ Judge Foster's opinion in this case adverted to the radical change made from discovery to percentage depletion by the 1926 Act as of January 1,1925, and stated that definitions of net income under the 1924 and previous acts were therefore immaterial. ${ }^{02}$ The opinion

apparent that the delimitation implied in the permission to deduct 'operating expenses' present under the earlier regulations disappeared from the 1926 regulations in case of oil and gas wells." Helvering v. Wilshire Oil Co., 60 Sup. Ct. 18, 24, n. 10 (U. S. 1939), rehearing denied, Dec. 11, 1939.

86. U. S. Treas. Reg. 74, Art. 221 (i).

87. Gen'1 Counsel Memo. 2315, VI-2 Cum. Bull. 21, issued September, 1927.

88. According to the Ninth Circuit Court of Appeals, the Commissioner attempted to say that the 1928 Act "no longer means what it meant when the Congress passed it," but what it was made to mean in 1932 when Congress reenacted the depletion clatuse without change. The circuit court of appeals held that the taxpayers were not required to have the "prescience to discern a difference in Congressional viewpoint two years in the ftture." Comm'r v. Wilshire Oil Co., 95 F. (2d) 971, 973 (C. C. A. 9th, 1938), revid, 60 Sup. Ct. 18 (U. S. 1939), rehearing denied, Dec. 11, 1939.

89. This argument is made by the Government in the Wilshire case in its bricf, pp. $7,16,27,28$.

90. No attempt is made in this discussion to cover other phases of the court's reasoning. The emphasis here is on the development of the principle established by the Reynalds case.

91. Comm'r v. F. H. E. Oil Co., 102 F. (2d) 596 (C. C. A. 5th, 1939), rev'g Board Memo. Op., C. C. H. B.T.A. Serv. Memo. Dec. No. $9751-B$, aff'd, 60 Sup. Ct. 26 (U. S. 1939).

92. This argument will be found at pp. 17 to 19 of the Government brief in the Wilshire case. The argument is that the depletion allowable previous to the 1926 Act for years previous to 1925 was discovery depletion which was changed in the 1926 Act to percentage depletion. 
admitted, probably erroneously, ${ }^{33}$ that while the old construction was continued under the 1926 Act for a time, it was changed in $1927 .^{\circ 1}$ Thereafter, beginning with Article 221(i) of Regulations 74, promulgated in February, 1929 under the 1928 Act, the administrative construction was formally changed so that it became substantially the same as the construction later adopted under the 1932 Act. $^{05}$ The court was therefore able to reason that the rule of legislative approval gained nothing from the enactment of the 1926 Act, since it was not applied under that act for a sufficiently long period ${ }^{96}$ to estop the Commissioner from changing it if he should be convinced that it was wrong. The court adopted the Government's argument that there should be consistent treatment, and held that the election to deduct intangible cost of drilling and development as expense bound the taxpayer to the same treatment in determining net income from the property for the purpose of applying the $50 \%$ net income percentage depletion limitation. ${ }^{97}$ Here was the square conflict sought by the Treasury; the Supreme Court was practically bound to intervene. It did so by granting certiorari in both the Wilshire ${ }^{98}$ and F. H. E. Oil ${ }^{93}$ cases.

We are not at the moment concerned with the effect of the Reymalds and Wilshire decisions from the standpoint of the immediate technical questions involved, but rather from the standpoint of their bearing on the broad question as to the effect of statutory reenactments upon outstanding executive constructions. In the I $W^{\prime}$ ilshire case the Government reiterated its insistence upon the "familiar" rule that successive or subsequent reenactment carries with it legislative approval of previous regulations. ${ }^{100}$ The Government then went on to distinguish the Reynolds case by limiting it to cases in which the Commissioner attempted to give a retroactiz' $e$ effect to amended regulations. The $W$ ilshire case was argued to involve no such attempt, but merely an attempt to apply an amended

93. See Helvering v. Wilshire Oil Co., 60 Sup. Ct. 18, 23, n. 10 (U. S. 1939), rchearing denied, Dec. 11, 1939.

94. See G. C. Memo. 2315, VI-2, Cusr. Bur.. 21 (1927). The Government did not claim so much as Judge Foster held, but merely that G. C. Alemo. 2315 foreshadowed an official change of position; Government Brief in Wilshire case, p. 22.

95. U. S. Treas. Reg. 77, Art. 221 (h).

96. It was applied for three years if the new rule can be counted as beginning with G. C. Memo. 2315; but if the announcement of the new rule required a formal Treasury: decision or regulation, the new rule had never been applied under the 1926 Act.

97. The court referred to the Ambassador and Wilshirc cases and stated that it did not "find these decisions persuasive."

98. Helvering v. Wilshire Oil Co., 306 U.S. 625 (1939).

99. F. H. E. Oil Co. v. Helvering, 307 U. S. 618 (1939).

100. See Government Brief in Wilshire case, p. 15, citing Helvering v. WWinmill, 305 U.S. 79, 83 (1938) ; Hassett v. Welch, 303 U. S. 303, 312 (1938) ; United States v. Dakota-Montana Oil Co., 288 U. S. 459, 466 (1933) ; Brewster v. Gage, 280 U. S. 327, 337 (1930). 
regulation prospectively. The Government thus surrendered the right of the Commissioner to apply new regulations retroactively to a period covered by old regulations which had been given legislative approval by statutory reenactment. ${ }^{101}$ The taxpayer, on the other hand, though there was confusion in the Wilshire situation as to whether any regulation was outstanding under the 1926 Act, was insisting upon the application of the Reynolds principle that reenactment incorporated a uniform interpretation of an ambiguous provision susceptible of various meanings.

The Supreme Court held against the taxpayer. ${ }^{102}$ It might have been enough for the Court simply to distinguish the Reynolds case, as it did, on the ground that it dealt with regulations applied retroactively, and that the Wilshire case involved a less uniform history of administrative construction. But fortunately for the enlightenment of taxpayers, the Court went further. The opinion of Mr. Justice Douglas is divisible into four parts, as follows:

(1) It was held that there was no basis for a claim of retroactivity. The new regulations, Regulations 74, Article 221(i), "applied prospectively only and did not purport to reach back to earlier years when the taxpayer relied upon a different rule or practice." ${ }^{103}$ One making an election in his 1925 return "took the risk" that the method of treatment of depletion might be changed by Congress or, where the power existed, by the Commissioner.

(2) A further answer to respondent's contention of inequity was that a new election with respect to the deduction of intangible development expense was given on June 18, 1927, extending for a six-months' period, during which period General Counsel Memorandum 2315 clearly stated to taxpayers the burdens which would flow from the benefits of deducting such costs as expense.

(3) Mr. Justice Douglas then stated the Court's opinion that the new regulations were valid irrespective of the above considerations because the administrative construction under the 1921 Act which had received legislative approval in the 1924 Act did not survive the enactment of the 1926 and 1928 Acts. There was no such administrative construction under the 1926 Act to which Congress could have given approval in the 1928 Act; the more reasonable inference was that the phrase "net income . . . from the property" had been restored to its original ambiguity,

101. The Government was up against a difficult choice. It had to distinguish the Rcynolds case or urge that that case was wrongly decided. It chose to distinguish the casc, which perhaps was all that was necessary in arguing the Wilshire case. Its next task may be to bring a case to the Supreme Court which will be indistinguishable so that the Supreme Court may have a square opportunity to reconsider the Reynolds doctrine.

102. Accord: F. H. E. Oil Co. v. Helvering, 60 Sup. Ct. 26 (U. S. 1939). See (1939) 53 Hakv. L. Rev. 323.

103. Helvering v. Wilshire Oil Co., 60 Sup. Ct. 18, 23 (U. S. 1939). 
which meant that it was again susceptible to a new administrative construction.

(4) The final line of argument sustained the validity of the contested regulations on broad grounds of administrative policy. For the Court wisely saw peril for the rule-making powers of the Commissioner. "Ta: statutes and tax regulations never have been static. Experience, changing needs, changing philosophies inevitably produce constant change in each." "Experience and new insight can be expected to produce rather constant change," particularly in connection with a technical subject. Restrictions on the rule-making power "should not be lightly imposed where the incidence of such rules as are promulgated is prospective only." 104

More than that. The entire statutory reenactment rule needed restating, at least in connection with prospective changes in regulations. The Court seized the occasion:

“. . The oft-repeated statement that administrative construction receives legislative approval by reenactment of a statutory provision, without material change . . . covers the situation where the validity of administrative action standing by itself may be dubious or where ambiguities in a statute or rules are resolved by reference to administrative practice prior to reenactment of a statute; and where it does not appear that the rule or practice has been changed by the administrative agency through exercise of its continuing rule-making power. It does not mean that a regulation interpreting a provision of one act becomes frozen into another act merely by reenactment of that provision, so that the administrative interpretation cannot be changed prospectively through exercise of appropriate rule-malking powers. . . . The contrary conclusion would not only drastically curtail the scope and materially impair the flexibility of administrative action; it would produce a most awkward situation. Outstanding regulations which had survived one Act could be changed only after a pre-view by the Congress. In preparation for a new revenue Act the Commissioner would have to prepare in advance new regulations covering old provisions. Their effectiveness would have to await Congressional approval of the new Act. The effect of such procedure, so far as time is concerned, would be precisely the same as if these new regulations were submitted to the Congress for approval. Such dilution of administrative powers would deprive the administrative process of some of its most valuable qualities ease of adjustment to change, flexibility in light of experience. swiftness in meeting new or emergency situations. It would make the administrative process under these circumstances cumbersome and slow: Known inequities in existing regulations would have to await the advent of a new revenue act. Paralysis in effort to keep abreast of changes in business practices and new conditions would redound

104. Helvering v. Wilshire Oil Co., 60 Sup. Ct. 18, 23, 25 (U. S. 1939), relcaring denied, Dec. 11, 1939. 
at times to the detriment of the revenue; at times to the disadvantage of the taxpayer. Likewise the result would be to read into the grant of express administrative powers an implied condition that they were not to be exercised unless, in effect, the Congress had consented. We do not believe that such impairment of the administrative process is consistent with the statutory scheme which the Congress has designed." 105

The Court could go no further in a case involving only a prospective change in the regulations. The warning to be served upon both Government and taxpayers is that the reenactment rule is not so broad as is sometimes supposed by those who would use it to their advantage where a retroactive change is made in the regulations. For the rule has its limitations, and will not lightly be stretched to cover cases in which there has been too little uniformity, or in which there is judicial disagreement, or in which the regulations are themselves ambiguous, or where the statute is plainly to the contrary. Even as to the past the rule has its principal application to ambiguous or general statutes where the old regulation takes a position in debatable territory. And as to the future, an amendment of the regulations may be a valid exercise of the Commissioner's power despite continued reenactment approving a prior practice. Moreover, the validity of such a prospective change may not have to await the sanction of a new reenactment of the statute.

The opinion in the Wilshire case affords the most satisfactory and incisive discussion of the reenactment rule that has yet been handed down by any court. Cogent and convincing arguments are advanced for some degree of flexibility in administrative interpretation. Although in view of our annual Congressional sessions the need for elasticity to meet changing business conditions may not be so crying a demand as the opinion makes it appear, nevertheless the Court's result was the inescapable practical solution. While the possibility of two different constructions placed upon the same statutory language may seem almost humorous in its lack of logical consistency, yet the law must often break through logical straitjackets. It is too much to expect that every regulation should originally be announced in perfect form; a Commissioner from whom such perfection was demanded would do nothing in preference to doing wrong at a severe penalty. And a statute is a living thing; it is not an unyielding mummy cloth in which the thoughts of Congress are rigidly wrapped and sealed forever.

Still the case suggests its dangers, which lead one to hope that the Treasury will apply its doctrine in accordance with rules of fairness. The Wilshire situation involved regulations offering the taxpayer certain benefits in the form of deductions if he were prepared to accept correlative burdens. Would the case permit the Commissioner to impose

105. Id. at 24. 
greater burdens upon the electing taxpayers by subsequent regulatory amendments, albeit they might operate only prospectively? That question was neatly sidestepped by the Court on the somewhat tenuous ground that an informal opinion issued approximately two months prior to the final date set for the taxpayer's election warned of the burdens to be assumed. One is forced to wonder what the result would have been had this General Counsel's Memorandum not been issued. Moreover, the fact that a hiatus in the regulations had apparently occurred under the 1926 Act, thereby restoring the statutory language as used in the 1928 Act to its "original ambiguity," prevents the opinion on its precise facts from being authority for any universal assumption that all regulations may be prospectively amended despite prior statutory reenactment. Nevertheless the language of the Court is sufficiently broad to cover a situation wherein the original administrative practice had been continuous and uniform. It is also so sweeping in its tenor as to render of little significance any distinction between purely interpretative regulations issued under the general aegis of Section 62 and regulations specifically authorized by particular provisions of the statute. ${ }^{103}$

\section{Conclusion}

Few problems are of more permanent importance in tax law than the administrative background of interpretative problems. Much ink, though perhaps less thought, has been devoted to the complexities of our tax laws. Without attempting to defend or attack this intricate structure, ${ }^{107}$ it must be pointed out that a complex business civilization breeds problems which cannot be met by a revenue act phrased in grammar-school English. And furthermore it is essential to a proper administration of the statutes that a flexible discretion be rested in the administrative authorities. Any doctrine analogous to estoppel or stare decisis as applied to administrative interpretations would defeat their very purpose. Especially is this true today in view of the innumerable Supreme Court decisions which represent the ultimate interpretation of our taxing statutes and which frequently necessitate a reversal or modification of existing administrative policies. On the other hand, the goodwill of taxpayers obviously cannot be maintained if the interpreting officials change their position with the agility of trapeze performers. Even though retroactive changes in the regulations or in more in formal bureau opinions

106. See (1939) 53 HARv. L. REv. 323, 324. In fact, contrary to the assumption of the Supreme Court, the regulation in the Wilshire case itself was hardly covered by the specific rule-making power as to depletion in $\$ 23(1)$, which may well not have been intended to extend to the specific percentage depletion provision in \$114(b) (3); Alvord, Treasury Regalations and the Wilshire Oil Case (Privately published manuscript, 1939) 5.

107. See Eichhoiz, Should the Federal Income Tax Bc Simplificd? (1939) 48 Yare L. J. 1200. 
may be legally justifiable, such practices lead to a feeling that no reliance can be placed upon bureau officials; and the average taxpayer, having no facilities to attack executive constructions, is not stimulated to any attitude of fairness in filing his returns or in his use of tax-reducing schemes.

The particular degree of weight to be given administrative rulings is hardly a question which can be reduced to mathematical rules by any statutory amendment; in the long run such a matter can best be left to the wisdom of the courts. Any specific legislation as to the contents or application of the regulations must take into account the promptness with which some fairly authoritative construction of the statute must be forthcoming. One possible remedy to prevent possible abuse of the regulatory power might be to require public hearings in the future upon all proposed interpretative or legislative regulations to be issued under new sections of the statute. Such hearings would at least afford a public airing to opposing views and serve to bring any serious inequities in the proposals to the attention of Congress. At the same time amendments to outstanding regulations could be discussed. It would clearly be selfdefeating, however, to have each new or amended regulation submitted to Congress, or to add a blanket statutory incorporation by reference of the outstanding regulations, since requiring such a legislative examination would run counter to the very objective of administrative delegation, by consuming the time and attention of the legislators. ${ }^{108}$

The retroactive evils of changed regulations, in so far as there may still be room for retroactive application, might be lessened if the Supreme Court were required to grant review to any circuit court of appeals or Court of Claims decision reaching a result in conflict with a Treasury regulation. It would then not be necessary to have such review await the generation of a conflict in the lower courts, which is now of ten a question of years. If the Supreme Court thereupon reverses the theory of the regulations, the retroactive period of the new regulations occasioned by the reversal will in many cases be considerably shortened. A still further possibility to ease the axe of retroactivity would be a provision that some agency such as the Board of Tax Appeals should,

108. The method of requiring regulations to be laid before the legislature prior to promulgation or prior to becoming finally effective has been a common technique in England where it has been found to have the disadvantage of "shifting back into Parlialment a discussion of things which Parliament had, with its eyes open, divested itself of." 2 Report of Committee on Ministers' Powers (1932) Minutes of Evidence, $\$ 3666$, p. 272, cited in Blachly and Oataran, Administrative Legislation and Adjudication (1934) 83. In questions of great importance, however, this method has the merit of bringing the legislature into closer contact with the administrative branch and of overcoming, through a legislative imprimatur, the hesitancy of the administrative authorities to accept responsibility by taking affirmative action. See Landis, The Administrative Process (1938) $77-78$. 
within a stated period, pass upon the reasonableness and validity of any retrospective amendment to the regulations. The Board's unquestioned technical equipment and competence in tax matters would assert itself favorably in such a function. ${ }^{109}$

109. The approval of administrative regulations by some agency or authority other than that which first drafts them is a common type of control. Such a method has the advantage that an authority or body not charged with the task of administration is naturally less partial and less departmentalized in its viewpoint. See BrncnLy a:ro OAтaras, op. cil. supra note 108 , at 84 . 